УДК 614.253 .52

Якимець В.М. ${ }^{1}$, Печиборщ В.П. ${ }^{1}$, Волянський П.Б. ${ }^{2}$, Кушнір В.А. ${ }^{2}$, Вороненко В.В. ${ }^{3}$, Слабкий Г.О. ${ }^{4}$

\title{
Функціональна підсистема медичного захисту населення при надзвичайних ситуаціях Сполучених Штатів Америки та України - порівняльна характеристика
}

\footnotetext{
${ }^{1}$ Державна наукова установа «Центр інноваційних медичних технологій Національної академії наук України»

${ }^{2}$ Інститут державного управління та наукових досліджень з цивільного захисту

${ }^{3}$ Державна установа «Науково-практичний медичний центр дитячої кардіології та кардіохірургії МО3 України»

${ }^{4}$ ДВНЗ «Ужгородський національний університет»
}

g.slabkiy@ukr.net

Якимец В.М. ${ }^{1}$, Печиборщ В.П. ${ }^{1}$, Волянский П.Б. ${ }^{2}$,

Кушнир В.А. ${ }^{2}$, Вороненко В.В. ${ }^{3}$, Слабкий Г.А. ${ }^{4}$

Функциональная подсистема медицинской защиты населения при чрезвычайных ситуациях

Соедененных Штатов Америки и Украины сравнительная характеристика

${ }^{1}$ Государственное научное учреждение

«Центр инновационных медицинских технологий

Национальной академии наук Украины»

${ }^{2}$ Институт государственного управления и научных исследований по гражданской защите

${ }^{3}$ Государственное учреждение «Научно-практический медицинский центр детской кардиологии

и кардиохирургии Министерства здравоохранения»

${ }^{4}$ ГВУЗ «Ужгородский национальный университет»
Yakimets V.M. ${ }^{1}$, Pechiborshch V.P. ${ }^{1}$, Volyansky P.B. ${ }^{2}$, Kushnir V.A. ${ }^{2}$, Voronenko V.V. ${ }^{3}$, Slabkiy G.O. ${ }^{4}$

The functional subsystem of medical protection of the population in emergency situations of the United States of America and Ukraine - a comparative characteristic

${ }^{1}$ State Scientific Institution "Center for Innovative Medical

Technologies of the National Academy of Sciences of Ukraine"

${ }^{2}$ Institute of Public Administration and Scientific Research on Civil Protection

${ }^{3}$ State Institution "Scientific and Practical Medical Center of Pediatric Cardiology and Cardiac Surgery of the Ministry of Health"

${ }^{4}$ Uzhhorod National University

\section{Вступ}

Ст. 49. Конституції України: «Кожен має право на охорону здоров'я, медичну допомогу та медичне страхування.

Охорона здоров'я забезпечується державним фінансуванням відповідних соціально-економічних, медико-санітарних і оздоровчо-профілактичних програм» [1].

3 набранням чинності 31 січня 2013 року Законом України «Про екстрену медичну допомогу» [2], та Кодексом цивільного захисту України [3], було відмінено цілий ряд Законів України та підзаконних актів що регламентували діяльність Державної служби медицини катастроф та функціональної підсистеми медичного захисту населення в Сдиній державній системі цивільного захисту потребувалось їх відновлення. 3 цією метою було підготовлено цілий ряд проектів нормативно-правових актів Кабінету Міністрів та МОЗ України спрямованих на адаптацію до вимог вище означених Закону та Кодексу, що вимагало проведення досліджень досвіду діяльності екстреної медичної допомоги в надзвичайних ситуаціях (далі - НC), особливостей існуючого нормативноправового забезпечення, організації взаємодії цивільної та військової систем охорони здоров'я на пострадянському просторі в Республіках Білорусь, Узбекистан, Казахстан, Російській Федерації та країнах далекого зарубіжжя США, Франції, ФРН, Швеції, Великобританії, Бельгії, Нідерландах, Швейцарії, Фінляндії, Норвегії, Ямайці та ЦО НАТО.

В результаті дослідження виявлено, що спільним для всіх держав с наявність систем постійної готовності до НС, а відмінності обумовлені національними, природно-географічними особливостями, соціально-економічними факторами, рівнем науково-технічного розвитку. Поряд із державними установами в роботі 3 надання допомоги потерпілим велике значення належить приватним та громадським організаціям.

Вивчення зарубіжного досвіду показує, що для кожної країни характерні свої особливості в створенні систем захисту і порятунку населення при НС. I хоча більшість авторів відзначає, що кращих результатів можна досягти при централізованому керівництві, досвід Франції свідчить про зворотне.

3 огляду на накопичений досвід по ліквідації медичних наслідків аварій і катастроф, фахівці на перший план висувають професійну підготовку кадрів, завчасне 
проведення заходів щодо забезпечення матеріальнотехнічної бази, зв'язок і взаємодія різних аварійнорятувальних служб, а також міжнародне співробітництво.

Отже, вивчення досвіду зарубіжних держав в організації допомоги ураженим в умовах НС відіграє вагому роль у вирішенні проблем медицини катастроф в Україні, що дозволить підвищити ефективність надання допомоги населенню в разі виникнення різних аварій і катастроф [4].

\section{Результати дослідження та їх обговорення}

США - федеративна республіка, поділена на 50 штатів, у складі яких - чисельні адміністративнотериторіальні й місцеві громади. У кожній громаді за єдиним законом, єдиними стандартами та протоколами працює єдина система невідкладної медичної допомоги (Emergency Medical Services - EMS), яка визнана однією з найефективніших і найдосконаліших систем ЕМД у світі. США розбудовували систему EMS протягом 80 років за єдиною концепцією, відповідною до неї програмою, нормативно-правовим забезпеченням, не шкодуючи на ii вдосконалення і діяльність мільярдних асигнувань.

Досвід медичного захисту США свідчить про те, що ліквідацією наслідків НС природного, техногенного соціального походження та терористичних актів, в першу чергу, займаються громади та органи влади населених пунктів, адміністративних територій, штатів. Система протидії негативним наслідкам їх власних територій складалась віками. У випадках, коли місцева громада, адміністративна територія чи навіть штат не в силах протидіяти $\mathrm{HC}$, негайно запрошується допомога Федерального Уряду, і починає діяти Національна система захисту населення та територій від НС. Ця система існувала в тій чи іншій формі протягом більше 200 років [4].

7-й конгрес США, ще в 1803 році прийняв правовий акт щодо надання матеріальної допомоги із Федерального бюджету для купців Портсмуту, потерпілим при пожежі. Американські історики починають 3 цієї дати відраховувати діяльність Федеративного уряду спрямовану на надання допомоги в процесі ліквідації наслідків НС.

Питання щодо уніфікації системи надання екстреної медичної допомоги в процесі ліквідації наслідків катастроф в усіх державах світу вперше було обговорено в 1975 р. в Женеві, де була організована
Міжнародна організація медицини катастроф. В 1976 р. створено «Клуб Майнца» Міжнародної спілки 3 невідкладної медицини та медицини катастроф, яка в 1983 р. була трансформована у Всесвітню асоціацію невідкладної медицини та медицини катастроф (WAEDM).

Згідно 3 розпорядженням президента США від квітня 1979 р. № 12127 було створене Федеральне управління в надзвичайних ситуаціях (HC) у США (Federal Emergency Management Agency - FEMA), яке сьогодні $\epsilon$ основним Федеральним відомством в НС, після чого почалось систематичне удосконалення функцій та можливостей. Водночас була зроблена спроба консолідувати кілька особливих функцій що призвело до співпраці FEMA з силами готовності до стихійних лих.

FEMA поглинає Федеральне управління страхування, Національне управління попередження пожеж, адміністрацію загальних служб та Федеральної допомоги при стихійних лихах.

Після подій 11 вересня 2001 р., терористичної атаки за допомогою цивільної авіації, Конгрес прийняв Закон щодо Національної безпеки, яким був посилений створений раніше Департамент національної безпеки (Department of national safety - DNS) для поліпшення координації та взаємодії між різними федеральними агентствами, які мають справу 3 правоохоронними органами, для підвищення готовності до стихійних лих та відновлення, охорони кордонів і цивільної оборони.

31 березня 2003 р. FEMA було підпорядковане DNS. Водночас з 31 березня ц.р. FEMA отримало попередній статус Федерального агентства 3 надзвичайних ситуацій та налічує більше 2600 штатних співробітників, але продовжує бути частиною системи аварійної готовності, реагування та управління Департаменту національної безпеки.

3 метою виявлення причин високого рівня готовності державної структури FЕМА і його сил і засобів у США та низького рівня показників готовності до виконання завдань за призначенням державної функціональної підсистеми медичного захисту населення в єдиній державній системі цивільного захисту доцільно порівняти деякі показники економічного і соціального розвитку та значимості на світовій арені США та України то вимальовується не втішна картина, яка засвідчує, що ці дві держави знаходяться на діаметрально протилежних полюсах [4,5] (див. табл. 1).

\section{Таблиця 1. Рейтинг показників США та України значимості на світовій арені}

\begin{tabular}{l|l|l}
\multicolumn{1}{c}{ № 3/п } & \multicolumn{1}{|c}{ США } & \multicolumn{1}{c}{ Україна } \\
\hline 1. & $\begin{array}{l}\text { Утримують першість за багатьма основними } \\
\text { показниками оцінки держави у світі - це } \\
\text { високорозвинена держава з розвиненою } \\
\text { конкурентно-здатною, наукоємною, } \\
\text { високотехнологічною економікою. }\end{array}$ & $\begin{array}{l}\text { В стані економічної, соціальної та політичної кризи } \\
\text { та ведення гібридної війни на сході України під } \\
\text { назвою Антитерористичної операції та Операцї̈ } \\
\text { об'єднаних сил (АТО/ООС). }\end{array}$ \\
$\begin{array}{l}\text { Високий рівень матеріального благополуччя } \\
\text { громадян. }\end{array}$ & $\begin{array}{l}\text { Більшість населення на грані виживання і в стані } \\
\text { бідності }\end{array}$ \\
\hline
\end{tabular}


3. Високий рівень соціального захисту дітей та непрацездатного за станом здоров'я та за віком населення.

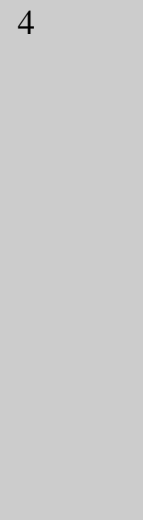

5.

Могутні збройні сили здатні протидіяти світовим загрозам, проявам міжнародного тероризму, захищати демократичні надбання не тільки громадян своєї держави, але і багатьох держав світу, які приєднались до певних міжнародних блоків чи структур, що очолює чи підтримує США.

6. Високий рівень готовності сил і засобів Федерального управління в надзвичайних ситуаціях (HC) у США (Federal Emergency Management Agency - FEMA) до виконання завдань за призначення як в США так і за їх межами забезпечує високий імідж цієї держави у світі

7. Медицина в США є пріоритетною сферою інтересів уряду: система охорони здоров'я, наукові дослідження, а також інші аспекти медицини тут у великій шані. Ця сфера постійно удосконалюється та розвивається.

Медицина притягує велику кількість тих, що бажають працювати в цьому середовищі:за даними за останні десять років зарплати в цьому сегменті тільки ростуть.

Серед висококваліфікованих спеціальностей медики є найвисокооплачуваними. В галузі працює більше 10 млн чол., і ще близько 2 млн здобувають вищу освіту в тій чи іншій сфері, пов'язаній 3 медициною.

Система охорони здоров'я спрямована на збереження здоров'я нації. Керує міністерством охорони здоров'я посадовець, який підпорядкований особисто президентові.

Аналіз небезпек виникнення надзвичайних ситуацій в США та Україні свідчить про те, що в США їх значно більше, але як свідчить досвід ліквідації надзвичайних ситуацій у цій країні, державні структури та
Соціальний захист дітей та непрацездатного за станом здоров'я та за віком населення не задовольняє їх потреби.

Система охорони здоров'я держави на другому етапі сумнівного малоефективного реформування. Запроваджені стандарти надання медичної допомоги відповідають світовим, але не забезпечують ії безкоштовно, окрім Екстреної медичної допомоги. «Положення про функціональну підсистему медичного захисту населення» та «Положення про медичну спеціалізовану службу цивільного захисту» затверджені наказами МО3 України від 25.03.2019 № 667 та 12.06.2019 № 1349 відповідно $[6,7]$. Виконання яких потребує виділення значних державних коштів.

На початок гібридної війни Збройні сили України були не спроможні захистить суверенитет i цілісність рубежів держави. На даний час в процесі реформування та приведення до стандартів НАТО, вони є основним діючим компонентом АТО та

OOC.

Сдина державна система цивільного захисту до якої входить функціональна підсистема медичного захисту в цілому на даний час забезпечує виконання завдань за призначенням при подоланні наслідків надзвичайних ситуацій.

Держава створює умови для ефективного і доступного для всіх громадян медичного обслуговування. У державних і комунальних закладах охорони здоров'я медична допомога надається безоплатно; існуюча мережа таких закладів не може бути скорочена. Держава сприяє розвиткові лікувальних закладів усіх форм власності» [1].

Система охорони здоров'я в Україні в стані реформування, яке не адаптоване до умов нашої держави яка знаходиться в стані економічної кризи. Часті зміни в керівництві відомства призводять до їх уповільнення та зривів у виконанні вимог етапів реформування та відповідних нормативних актів держави. Заробітна плата медиків найнижча серед усіх спеціальностей, тому велика кількість лікарів їдуть працювати за кордон.

Міністерство підпорядковується Прем’єр-міністру України.

наявні сили і засоби гарантують забезпечення безпеки своїх громадян, територій, об'єктів промисловості, населених пунктів та спроможні виконати завдання за призначенням у повному обсязі (див. табл. 2) 


\section{Таблиця 2. Небезпеки виникнення надзвичайних ситуацій США та України}

\begin{tabular}{|c|c|c|}
\hline № 3/II & США & Україна \\
\hline 1. & $\begin{array}{l}\text { Географічне положення США, океани, що } \\
\text { омивають західне і східне побережжя держави, не } \\
\text { завжди сприятливі кліматичні умови (буревії, } \\
\text { урагани, смерчі тощо). }\end{array}$ & $\begin{array}{l}\text { Знаходиться в помірному кліматичному поясі зі } \\
\text { сприятливими кліматичними умовами, але } \epsilon \\
\text { небезпеки буревї̈в. }\end{array}$ \\
\hline 2. & $\begin{array}{l}\text { Небезпеки землетрусів, призводять до частих } \\
\text { катастроф природного характеру: землетрусів, } \\
\text { затоплень та руйнування значних по розміру } \\
\text { територій з досить високим рівнем населеності, } \\
\text { яким держава - однією з перших в світі - } \\
\text { навчилась активно і сиайних ситуцій стемно } \\
\text { протидіяти. }\end{array}$ & $\begin{array}{l}\text { Паводки та підтоплення бувають в Закарпатті, } \\
\text { Прикарпатті та в гирлі Дунаю в Одеській області. } \\
\text { Сил і засобів Державної служби України } 3 \\
\text { надзвичайних ситуацій достатньо. }\end{array}$ \\
\hline 3. & $\begin{array}{l}\text { Могутня сучасна енергоємна новітня } \\
\text { промисловість створює небезпеки прояву } \\
\text { техногенних катастроф. }\end{array}$ & $\begin{array}{l}\text { Застаріле устаткування та обладнання } \\
\text { промислових підприємств вугледобувної, хімічної } \\
\text { промисловості та енергетики створює передумови } \\
\text { для виникнення НС техногенного характеру }\end{array}$ \\
\hline 4. & $\begin{array}{l}\text { Зовнішня політика протидії агресивним } \\
\text { політичним режимам, проблеми захисту свобод } \\
\text { людини в усіх державах світу, викликають } \\
\text { протидію тоталітарних керівників окремих держав. }\end{array}$ & $\begin{array}{l}\text { Миролюбива зовнішня політика не забезпечує } \\
\text { миру на сході України та повернення до їі складу } \\
\text { анексованої Автономної республіки Крим. }\end{array}$ \\
\hline 5. & $\begin{array}{l}\text { США є об'єктом прояву організованого тероризму, } \\
\text { лідером протистоянь воєнним провокаціям та } \\
\text { зазіханням. }\end{array}$ & $\begin{array}{l}\text { Гібридна війна на сході України та анексований } \\
\text { Крим є показником неспроможності протистояти } \\
\text { воєнним провокаціям та зазіханням на } \\
\text { територіальну цілісність держави. }\end{array}$ \\
\hline 6. & $\begin{array}{l}\text { Уряд і народ США велику увагу приділяють } \\
\text { гарантіям безпеки своїх громадян, територій, } \\
\text { об’єктів промисловості, населених пунктів. }\end{array}$ & $\begin{array}{l}\text { Нинішнє керівництво держави велику увагу } \\
\text { приділяє гарантіям безпеки своїх громадян, } \\
\text { територій, об’єктів промисловості, населених } \\
\text { пунктів. }\end{array}$ \\
\hline
\end{tabular}

Федеральним Законом «Emergency Medical Services» 1973 р., визначений розподіл повноважень між Федерацією та місцевими органами державної влади. На Федеральну владу покладається створення нормативноправової бази (закони, протоколи рівня та обсягу медичної допомоги, загальні вимоги обсягу підготовки фахівців, системи їх атестування та сертифікації, стандарти транспортних засобів, обладнання та фахівців медицини невідкладних станів (МНС)). На владу штатів та окремих регіонів - забезпечення реалізації вимог Федеральних законів і наказів, їх деталізація та адаптація до своїх умов, створення служби ЕМД та визначення додаткових до федеральних власних можливостей та джерел фінансування.

Кожний штат має агентство з ЕМД, на яке покладена координація діяльності служб ЕМД та контроль виконання ними вимог законодавства та стандартів. Водночас в більшості штатів існують представницькі органи консультативні комітети ЕМД, до складу яких входять висококваліфіковані, авторитетні медичні працівники та представники населення - споживачі послуг ЕМД. Агентство очолює лікар з МНС, який керується вимогами Закону «Emergency Medical Services» та взаємодіє з низкою юридичних, контролюючих, плануючих організацій, які адміністративно і фінансово незалежні від стандартної системи ЕМД, але визначають i ведуть реєстри сертифікованих фахівців системи та іiі санітарного автотранспорту; навчальних закладів, що готують фахівців для системи; сил і засобів для реалізації функцій системи залежно від особливостей регіону (щільність населення, інфраструктура транспортних систем, наявність особливостей впливу несприятливих природних ризиків узбережжя океанів, бурхливих річок тощо).

На випадки виникнення, з урахуванням ризиків на території штату НС природного чи техногенного характеру законодавством передбачене включення до складу ЕМД США, санітарних авіаційних транспортних засобів (гелікоптери, літаки), санітарних плавзасобів тощо. Ці окремі складові служби фінансово та адміністративно незалежні від основної системи ЕМД і зазвичай фінансуються штатом окремо. Ці складові взаємозалежні функціонально і з метою чіткої взаємодії потребують узгодженого планування, стандартизації та взаємного коригування всіх видів діяльності.

Водночас можуть залучатись автомобільні транспортні засоби інших відомств та організацій, санітарна авіація (гелікоптери, літаки), транспортні засоби річкових та морських санітарних суден, які за особливих умов регіонів (гори, ріки, морське узбережжя) виконують допоміжні функції. Підготовка особового складу всіх зазначених транспортних засобів відповідає законодавству.

Система ЕМД США складається зі служб, утворених за адміністративно- територіальними та 
територіальними ознаками. У склад служби НМД входять: система виклику ЕМД (телефон 911 та відповідна диспетчерська служба), зв'язку та інформації, транспортні засоби служби, госпітальна база, агентства громадської безпеки, особовий склад служби, система підготовки особового складу та пацієнти. Окремі складові служби фінансово та адміністративно незалежні. Але їх робота направлена на надання допомоги конкретним пацієнтам, тому вони взаємозалежні функціонально, що потребує узгодженого планування, стандартизації та взаємного коригування всіх видів діяльності. На всіх етапах ЕМД за рахунок уніфікації (єдині стандарти, протоколи сортування та лікування, єдине медичне керування всім процесом) забезпечується наступність і послідовність лікування. Елементи інтенсивної терапії з підтримки життєдіяльності постраждалого (ALS) виносяться до місця події [5].

До особового складу системи ЕМД США відносяться: - лікарі ЕМД, які готуються в резидентурі, не входять в рухомий склад бригад ЕМД і керують діями рухомого складу за допомогою сучасного зв'язку. Вони працюють в стаціонарах ЕМД, організують роботу системи, їх оплата підтримується на рівні лікарів - вузьких спеціалістів-клініцистів; - середні медичні працівники ЕМД, які працюють в стаціонарних закладах; - рухомий склад санітарних автомашин ЕМД: «Emergency Medical Technicians» (EMT) - медичні техніки 3 ЕМД та «paramedics» - парамедики. Це спеціально підготовані фахівці, які не мають вищої чи середньої спеціальної медичної освіти, технічно виконують передбачені протоколами відповідні стану постраждалого медичні процедури. у США особовий склад усіх бригад НМД парамедики та ЕМТ [34].

У більшості штатів є три рівні невідкладної медичної спеціальної підготовки медичних техніків 3 ЕМД: - перший рівень (ЕМТ-Ш) - нижчий рівень підготовки, на якому навчають вилучити постраждалого 3 аварійного транспортного засобу, зруйнованої будівлі тощо, правильно його іммобілізувати та транспортувати до лікувального закладу, дають практичні навички першої медичної допомоги та здійснення серцево-легеневої реанімації; - другий рівень (ЕМТ-П) - рівень проміжної медичної допомоги.

Крім програми першого рівня, тут оволодівають технікою пункції та катетеризації вен, використання пневматичних протишокових костюмів, введення зонда в шлунок та методикою ендотрахеальної інтубації; - третій рівень (ЕМТ-Р) - найвищий рівень парамедика, додатково включає медикаментозну терапію невідкладних станів, розшифровку ЕКГ, проведення дефібриляції. Термін підготовки парамедика - близько 1200 годин [24].

До особового складу системи НМД відноситься також персонал диспетчерського телефону 911, спеціально підготовані по програмам «ЕМТ» поліцейські, пожежники, працівники суспільних транспортних засобів (водії, кондуктори, стюардеси, провідники залізничного транспорту), працівники дитячих установ тощо. Весь особовий склад системи НМД може бути штатним, позаштатним, волонтерським. Кожний працюючий зобов'язаний мати відповідну до законодавства підготовку, бути вчасно атестованим, мати ліцензію на конкретний вид діяльності в системі НМД. Усі працюючі підлягають обліку в органах охорони здоров'я, працюють за контрактом, несуть юридичну відповідальність за свою діяльність (бездіяльність), чергують за затвердженими графіками, виконують вимоги досить жорстоких дисциплінарних правил функціональної вертикалі. 3 пацієнтами всі вони працюють за єдиними правилами. 3 місця події постраждалий транспортується в лікувальний заклад відомчим автотранспортом, санітарним автотранспортом пожежників, поліції, збройних сил, приватних волонтерів, суспільними та муніципальними санітарними автомобілями НМД, вертольотами та літаками санітарної авіації, водним транспортом.

Машини НМД відповідають федеральним стандартам DOT (КKК 1822C) щодо комплектації обладнанням, медикаментами, умов для розміщення пацієнта 3 метою надання адекватної ЕМД, використовуючи інвазивні методи лікування. Вертольоти розміщують не далі ніж на 150 миль, а санітарні літаки не менш ніж на 150 миль від місця обслуговування $[25,26]$.

Три етапи визначають алгоритм надання ЕМД: виклик бригади ЕМД для надання допомоги; догоспітальний та ранній госпітальний. Виклик бригади ЕМД як правило, здійснюється по телефону за номером 911.

Унікальна автоматизована система зв'язку здатна терміново надати стійкий зв'язок 3 найближчою до місця пригоди диспетчерською і сповістити іï про місце знаходження і номер телефону з місця виклику, навіть якщо пацієнт знепритомнів або поклав трубку. До цієі системи зв'язку входять пожежники, поліція, рятувальники штату які мають провідний телефонний, радіозв'язок, супутниковий мобільний зв'язок тощо.

3 метою стабільної роботи диспетчерської служби та медичних комунікацій, включаючи телеметрію Федеральною комісією комунікацій (Federal Communications Commission - FCC) для ЕМД виділені певні радіочастоти в діапазонах дуже високих та ультрависоких частот. Між спеціалізованим транспортом i лікувальним закладом діють функціональні канали зв'язку для передачі кардіограм, моніторингу основних фізіологічних параметрів хворого.

Стандартом DOT (ККК 1822C) штатний водій санітарного транспортного засобу відсутній і передбачено, що кожний член бригади працює за контрактом, має певний рівень підготовки, внесений до реєстру і, згідно 3 контрактом, має відповідну підготовку до додаткового виконання обов'язків водія санітарного транспорту щодо обслуговування автомобіля на місці виклику, при перевезенні хворого та при підготовці до чергового виїзду. За це він отримує відповідну надбавку до заробітної плати, яка визначена в його контракті.

Згідно 3 Федеральним стандартом DOT (КKK 1822C), санітарно-трансортні засоби забезпечені на $100 \%$ обов'язковим обладнанням, медикаментами, умовами для розміщення пацієнта [16]. Весь санітарний транспорт укомплектований та обладнаний згідно 3 вимогами для надання сучасної невідкладної медичної допомоги 3 
використанням інвазивних методів надання допомоги при різних НС. Стандарт вимагає при чергуванні на санітарному автомобілі наявності двох медичних техніків певного рівня підготовки. Місця чергування автотранспорту ЕМД мають бути наближені до місць проживання населення на певну відстань. Так, в сільській місцевості відстань від місця чергування автотранспорту не може перевищувати 30-хвилинний період під’їзду до найвіддаленіших об'єктів.

До відносять Багатопрофільні лікарні, спеціалізовані центри (опікові, травми, травм хребта, інтенсивної терапії новонароджених і дітей) складають госпітальну основу медичних закладів обслуговування пацієнтів у системі ЕМД. Водночас в державі інтенсивно розвиваються центри травми 1-, 2- та 3-го рівня i травматологічні заклади 4-го рівня та діють «Стандарти для оптимального лікування пацієнтів із травмою».

Служби ЕМД при госпіталізації постраждалого 3 травмою сьогодні стали надавати перевагу центрам травми. При цьому між лікарнями укладаються угоди щодо подальшого переводу пацієнтів в інші лікувальні заклади для надання спеціалізованої медичної допомоги та реабілітації. Порівняльна характеристика з Українською системою ЕМД (див. табл. 3).

\section{Таблиця 3. Порівняльна характеристика функціональної підсистеми медичного захисту США та України}

\begin{tabular}{l|c|}
\multicolumn{1}{c}{ № 3/п } & \multicolumn{1}{c}{ США } \\
1. & \multicolumn{1}{|c}{ Медична допомога при НС здійснюється в } \\
рамках Національної системи медицини катастроф \\
(National Disaster Medical System - NDMS), яка \\
входить до сфери управління і \\
найважливіших складових FEMA.
\end{tabular}

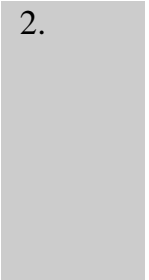

3.
Відповідальними за іiі стан є Міністерство охорони здоров'я та соціального забезпечення та Міністерство оборони, які займаються в масштабах федерації плануванням організаційних, медичних та евакуаційних заходів.

Концепція i структура сучасної
«Національної системи медичного забезпечення населення при катастрофах» (National system of the medical providing of population at catastrophes NDMS) були сформульовані вперше на початку 70-х років минулого століття.

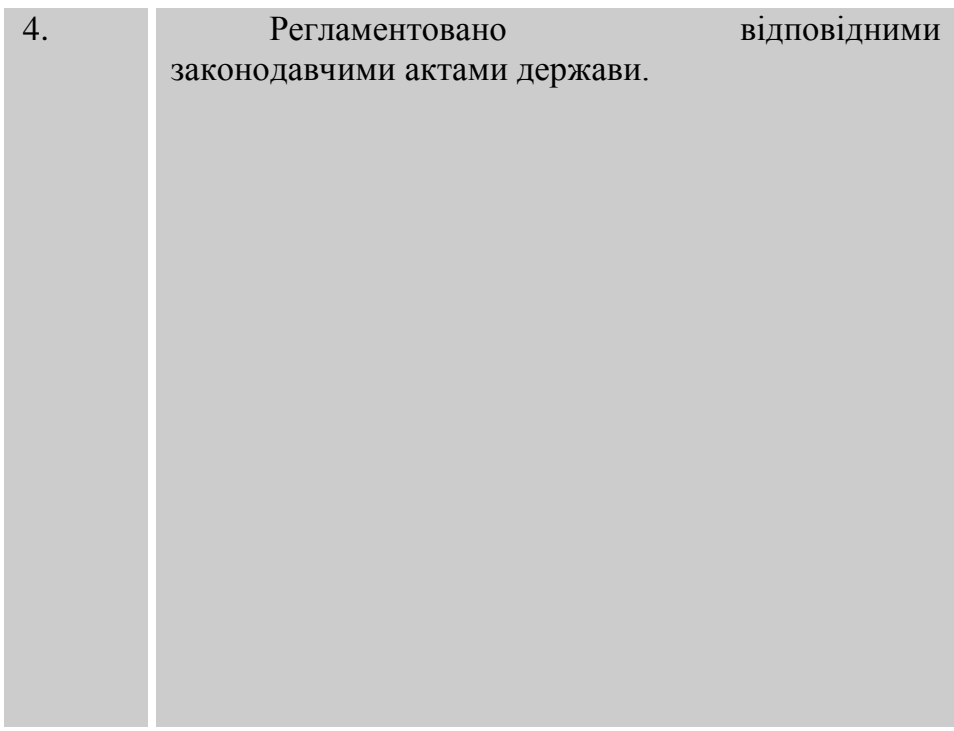

\section{Україна}

Згідно з постановою КМУ від 11.02.2001 p. № 827 «Про затвердження Положення про Державну службу медицини катастроф» [8] до складу Служби входять входять медичні сили і засоби та лікувально-профілактичні заклади центрального і територіального рівня незалежно від виду діяльності та галузевої належності, визначені MO3 за погодженням з ними.

Функціональна підсистема медичного захисту - складова частина єдиної державної системи цивільного захисту, до якої входять МО3, органи управління, підпорядковані їм сили цивільного захисту, суб'єкти господарювання у сфері охорони здоров'я, які виконують завдання цивільного захисту.

Постанова КМУ від 11.07.2001 р. № 827 «Про затвердження Положення про Державну службу медицини катастроф» [8], розпорядження КМУ від 22.05.2019 р. № 383-p «Про схвалення Концепції розвитку системи екстреної медичної допомоги» [9] заходи щодо поліпшення стану справ у функціональній підсистемі медичного захисту не передбачені.

У період дії надзвичайного стану (в разі його введення) функціональна підсистема функціонує відповідно до вимог Кодексу цивільного захисту України та 3 урахуванням особливостей, що визначаються згідно із Законом України «Про правовий режим надзвичайного стану» [10] та іншими нормативно-правовими актами.

В особливий період функціональна підсистема функціонує відповідно до вимог Кодексу цивільного захисту України та 3 урахуванням особливостей, що визначаються згідно із законами України «Про правовий режим воєнного стану»[11], «Про мобілізаційну підготовку та мобілізацію» [12], а також іншими нормативноправовими актами. Підготовка функціональної підсистеми до виконання завдань цивільного захисту в умовах особливого періоду здійснюється завчасно у мирний час. 
5.

На державному рівні дії системи детально плануються в Плані Федерального реагування, а на регіональному - дії кожного штату також сплановані в Планах реагування конкретного штату, регіону, району, місцевості.

План побудований за функціональним підходом до формування різних видів допомоги за 12 факторами підтримки в НС. Кожний із 12 факторів очолюється центральним органом державної виконавчої влади (Міністерством, відомством) відповідно до його сфери управління. Вводиться в дію План Указом Президента, згідно з яким призначається федеральний координатор всіх дій в зоні НС. Виконання Федерального Плану передбачає використання наступних складових:

1) транспорту,

2) зв'язку,

3) громадських та інженерних робіт,

4) використання сил і засобів пожежної служби,

5) взаємного інформування сил і засобів залучених до ліквідації наслідків НС і та уточнення заходів планування ліквідації наслідків НС,

6) піклування про населення,

7) ресурсної підтримки,

8) медичного забезпечення,

9) використання служби пошуку та

спасіння,

10) індикація шкідливих речовин,

11) харчування,

12) енергопостачання.

Додаткові функції, що виходять за межі Плану це: додаткове фінансування, інформування населення через засоби масового інформування, відношення 3 Конгресом - покладається на конкретних функціонерів Федерального агентства боротьби з надзвичайними ситуаціями.

6.

Основна функція підтримки медичного забезпечення в НС покладається на міністерство охорони здоров'я. Виконавець цієї функції помічник Міністра охорони здоров'я - керівник служби Федеральної охорони здоров'я.

7.

Головним органом управління медичним забезпеченням в НС є Штаб МОЗ готовності до НС, у складі працівників апарату - помічника Міністра охорони здоров'я - керівника служби Федеральної охорони здоров'я.
Функціональна підсистема проводить свою діяльність відповідно до планів основних заходів цивільного захисту МО3 на рік, підготовка яких проводиться з урахуванням заходів плану основних заходів цивільного захисту України на відповідний рік.

Структурні підрозділи 3 питань охорони здоров'я обласних, Київської та Севастопольської міських державних адміністрацій, суб'єкти господарювання у сфері охорони здоров'я реалізують заходи цивільного захисту у сфері охорони здоров'я на підставі планів основних заходів цивільного захисту на відповідний рік.

- Проведення заходів 3 ліквідації наслідків надзвичайних ситуацій здійснюється згідно $з$ планами реагування на надзвичайні ситуації відповідного рівня, які розробляються:

- на державному рівні - MO3; - у масштабі суб'єкта господарювання - суб'єктами господарювання у сфері охорони здоров'я 3 чисельністю працюючого персоналу понад 50 осіб; об'єкт господарювання у сфері охорони здоров'я 3 чисельністю працюючого персоналу 50 осіб і менше розробляє та затверджує інструкцію щодо дій персоналу у разі загрози або виникнення надзвичайних ситуацій [6].

Безпосереднє керівництво функціональною підсистемою здійснює Міністр охорони здоров'я України.

До складу функціональної підсистеми входять МОЗ, суб'єкти господарювання у сфері охорони здоров'я та сили цивільного захисту[6].

Постійно діючими органами управління функціональної підсистеми є:

- на державному рівні - MO3 (Сектор мобілізаційної роботи та цивільного захисту, Департамент впровадження реформ).

- на регіональному рівні - МОЗ АР Крим, структурні підрозділи з питань охорони здоров'я обласних, Київської та Севастопольської міських державних адміністрацій;

- на місцевому рівні - районні, районні у містах Києві та Севастополі державні адміністрації, підрозділи (призначені посадові особи) 3 питань охорони здоров'я виконавчих органів міських (міст республіканського АР Крим, міст обласного і районного значення) рад; 


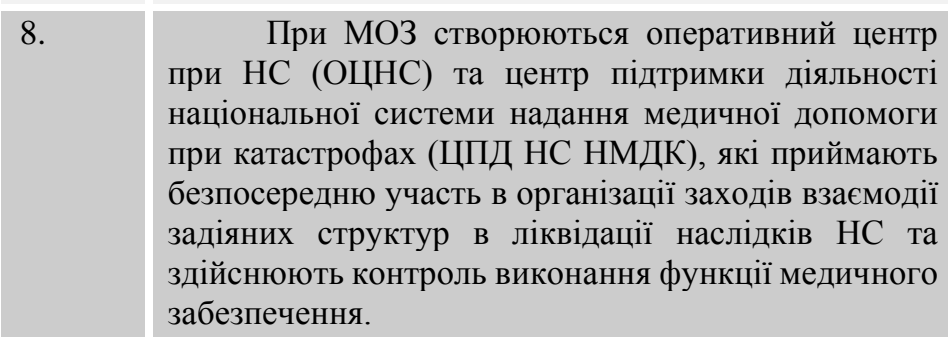

9. $\mathrm{HC}$

Завдання медичного забезпечення:

- піклування про здоров’я населення зони

- медичне сортування, надання медичної допомоги та евакуація уражених із зони $\mathrm{HC}$;

- евакуація уражених в 303 різних відомств - військових госпіталів, лікувальних закладів для ветеранів, медичних закладів різних форм власності, що завчасно виділяються рагіонами держави для ліквідації наслідків НС. на об'єктовому рівні - керівники суб'єктів господарювання у сфері охорони здоров'я та спеціально призначені посадові особи 3 питань цивільного захисту [6].

Під час ліквідації наслідків надзвичайних ситуацій управління силами цивільного захисту здійснюється 3 пунктів управління в пунктах постійної дислокації. Для забезпечення сталого управління у сфері охорони здоров'я та реалізації функцій, передбачених на особливий період, МО3 використовує державну систему пунктів управління. Для управління функціональною підсистемою використовуються телекомунікаційні мережі загального користування і спеціального призначення, а також державна система урядового зв'язку[6] та згідно з вимогами Закону України «Про систему екстреної допомоги населенню за єдиним телефонним номером 112» від 13.03.2012 р. № 4499 [13].

Розроблені та надані наступні пропозиції до проектів наказів МОЗ України:

- «Про затвердження Положення про Координаційну раду МО3 України 3 питань екстреної медичної допомоги та медицини катастроф»;

- «Про затвердження Положення про Державну службу медицини катастроф»;

- «Про затвердження Положення про основні підрозділи Державної служби медицини катастроф та медичного захисту населення в єдиній державній системі цивільного захисту».

Згідно з наказом МОЗ України від 25.03. 2019 № 667 Завданнями функціональної підсистеми є:

- здійснення заходів цивільного захисту суб'єктів господарювання у сфері охорони здоров'я;

- забезпечення готовності сил і засобів до дій, забезпечення реалізації заходів щодо запобігання виникненню надзвичайних ситуацій і небезпечних подій на суб'єктах господарювання у сфері охорони здоров'я та реагування на надзвичайні ситуації;

- організація та проведення моніторингу i прогнозування виникнення надзвичайних ситуацій та їх розвитку у сфері охорони здоров'я, визначення ризиків виникнення надзвичайних ситуацій на суб'єктах господарювання у сфері охорони здоров'я відповідно до повноважень;

- своєчасне i достовірне інформування заінтересованих органів виконавчої влади та населення про загрозу виникнення або виникнення надзвичайних ситуацій на суб'єктах господарювання у сфері охорони здоров'я;

- надання медичної допомоги постраждалим внаслідок надзвичайних ситуацій;

- взяття участі у рятувальних та інших невідкладних роботах 3 ліквідації наслідків надзвичайних ситуацій;

- забезпечення планування заходів цивільного захисту відповідно до функціонального призначення підсистеми; 
- організація та проведення навчань (тренувань) з підготовки суб'єктів господарювання у сфері охорони здоров'я та сил цивільного захисту; - розроблення та здійснення заходів, спрямованих на забезпечення сталого функціонування суб'єктів господарювання у сфері охорони здоров'я, або залучення МОЗ до виконання мобілізаційних завдань в особливий період;

- навчання працівників суб'єктів господарювання у сфері охорони здоров'я щодо поведінки та дій у разі виникнення надзвичайної ситуації;

- навчання населення щодо поведінки та дій у разі виникнення надзвичайної ситуації відповідно до функціонального призначення підсистеми;

- здійснення заходів щодо укриття персоналу та хворих (пацієнтів), суб'єктів господарювання у сфері охорони здоров'я у захисних спорудах цивільного захисту;

- розроблення та забезпечення виконання програм і планів з питань цивільного захисту;

- створення, збереження i раціональне використання резерву матеріальних ресурсів, необхідних для запобігання надзвичайним ситуаціям та реагування на них;

- виконання інших завдань у сфері цивільного захисту щодо забезпечення медичного захисту населення, передбачених законодавством України [6].

Крім МО3 до виконання завдань залучаються міністерства і відомства: оборони, юстиції, із справ ветеранів, транспорту, агентство по міжнародному розвитку, Червоний Хрест, агентство із захисту навколишнього середовища, управління загальними службами, національна система зв'язку, поштова служба США.

Основними мобільними формуваннями NDMS є Допоміжні команди медицини катастроф США, або (Disaster Medicine Assistant Team DMAT), які організуються для надання медичної допомоги постраждалим в осередку катастрофи і підсилення місцевої мережі охорони здоров'я в системі Національної системи медицини катастроф в якості функціональної одиниці.

Ці команди створюються при провідних медичних установах, медичних факультетах університетів у складі 36-120 волонтерів: лікарів, медичних сестер, парамедиків та персоналу матеріально-технічної підтримки.

Паралельно з DMAT-ами NDMS створює так називаємі Сили швидкого реагування (Rapid Deploymen Force - RDF) - це команди попередньої розвідки та допомоги. Кожна команда включає 105 фахівців різного профілю. Для розгортання своїх підрозділів команда потребує до 12 годин.

Крім RDF для визначення потреб системи охорони здоров'я щодо ліквідації даної НС створюються Команди прикладної охорони здоров'я, які протягом 36 годин розгортають
До складу сил цивільного захисту функціональної підсистеми входять:

- галузева медична спеціалізована служба цивільного захисту;

- територіальні та об'єктові медичні спеціалізовані служби цивільного захисту;

- підрозділи системи екстреної медичної допомоги та медицини катастроф;

- спеціалізовані медичні загони; спеціалізовані медичні бригади;

- групи радіаційного спостереження i дозиметричного контролю;

контролю;

групи хімічного спостереження i

- групи епідеміологічного спостереження і контролю;

- дезінфекційні бригади;

- інші формування цивільного захисту;

- добровільні формування цивільного захисту[6]. 
відповідні засоби, здійснюють розвідку та допомагають місцевим органам влади в керівництві подолання кризи. До складу команди включаються експерти з організації охорони здоров'я.

Федеральні лікарні за планами також стають координаційними центрами федеральних та регіональних сил для розгортання додаткової лікарняної бази та мобільних бригад для роботи в зоні НС. В залежності від структури та ліжкового фонду лікарні створюються різні, бригади від 30 до 100 добровольців лікарів, медсестер, технічного персоналу лабораторій, рентгенкабінетів тощо.

NDMS включає велику кількість інших формувань, які надають медичну та суміжні допомоги жертвам стихійних лих. Ці групи включають в себе лікарів, медсестер, фармацевтів і т.Д., і, як правило, мають підтримку лікарень, державних органів безпеки або приватних організацій. Крім того, додатково підсилюються формуваннями швидкого розгортання (RDF). Діють також національні групи реагування (NNRT), національних груп реагування щодо забезпечення медикаментами (NPRT) i ветеринарні групи медичної допомоги (VMAT). Для організації ліквідації проблем, пов'язаних 3 патологоанатомічною роботою та похованням загинувших розгортаються групи реагування (DMORT), що вирішують ці проблеми. Створюються i діють формування (ЯМРТ) обладнані для знезараження жертв хімічних i біологічних агентів, пошуково-рятувальних формувань (US\&R), мобільної підтримки операцій 3 реагування на НС (РВК).

За досвідом при ліквідації медико-санітарних наслідків великих за обсягом НС можливості мобільних формувань служб екстреної (швидкої, невідкладної) медичної допомоги, для надання ЕМД постраждалим в зоні $\mathrm{HC}$, поза межами лікувального закладу, навіть у найбільш розвинених країнах недостатні.

\begin{tabular}{|c|c|}
\hline 12. & $\begin{array}{l}\text { План реагування на внутрішні } \\
\text { катастрофи в закладі: } \\
\text { - пожежа, викид великої кількості пари, } \\
\text { руйнація окремих корпусів, приміщень в лікарні, чи } \\
\text { поблизу неї; } \\
\text { - основна особливість планування: детальне } \\
\text { вирішення проблем евакуації хворих та лікувальних } \\
\text { підрозділів в інші корпуса лікарні, чи в раніше } \\
\text { визначені приміщення за їі межами. } \\
\text { План реагування на зовнішні катастрофи } \\
\text { (за межами лікарні): } \\
\text { - планується утворення і направлення в район } \\
\text { катастрофи фахівців, організаторів створення } \\
\text { виносного сортувального підрозділу та початку } \\
\text { невідкладних дій щодо організації ліквідації } \\
\text { медико-санітарних наслідків НС на місці в районі } \\
\text { катастрофи; } \\
\text { - спеціалізовані мобільні бригади та } \\
\text { додаткове обладнання: яке передбачене Планами та }\end{array}$ \\
\hline
\end{tabular}


зберігається в лікарнях, це: різнокольорові жилети для представників різних служб, кольорові прапори та флагштоки для позначення різних пунктів, трасировочний матеріал, кольорові ракети та вогні, сортувальні бирки, паперові (та електронні) формуляри для записів та сортування, для забезпечення життєдіяльності та функціонування рятувальників i жертв (портативні джерела електроенергії). Освітлювальні прилади, переносні рації, кисень, лопати, кирки, сокири, тощо, ємності 3 чистою водою, продукти харчування, простирадла та згідно з табелями медичне обладнання, оснащення, медикаменти та виробами медичного призначення.

Після завершення боротьби 3 катастрофою, відповідальні за матеріальні цінності складають звіти про втрати та використання ресурсів, рештки повертають в лікарню, i адміністрація лікарні поповнює резерви до табельних норм;

- планується прийом, розміщення та лікування великого напливу постраждалих; мобілізується додатковий штат співробітників лікарні;

- відміняються планові операції та процедури, відтермінування яких можливе за медичними показаннями;

- налагоджується прямий зв'язок 3 керівництвом штату, організаторами боротьби 3 катастрофою на місці пригоди для детальної координації розподілу постраждалих в дану лікарню та інші регіональні лікарні.

13. Концепція реалізації Планів полягає в тому, що при НС (катастрофах), отримавши інформацію 3 місця катастрофи, негайно вступає в дію регіональний План. До місця катастрофи висуваються регіональні мобільні елементи реагування: пожежники, поліція, бригади швидкої медичної допомоги, які формують біля місця катастрофи командний пункт. Починається виконання своїх обов'язків рятувальниками кожного напрямку і одночасно детальна розвідка наслідків катастрофи та ії поширення.

Інформація подається через центр зв'язку, після чого здійснюється оцінка обстановки, розміру санітарних втрат, стану небезпеки для населення i перші прогнози щодо потреб в додаткових силах для ліквідації наслідків НС.

За необхідності губернатор Штату направляє сили та засоби, які він має згідно з регіональним Планом, доповідає про $\mathrm{HC}$ i ii наслідки Федеральному агентству боротьби з надзвичайними ситуаціями i у випадку необхідності просить допомогу. Федеральний уряд у цьому випадку негайно приймає відповідальність за управління всіма діями по реагуванню на $\mathrm{HC}$ i вводить практично в дію Федеральний План.

Слід відмітити, що Федеральний План $є$ кульмінацією дій 26 федеральних агентств боротьби 3 надзвичайними ситуаціями $\mathrm{i}$ відомств та Червоного Хреста. взаємодія організовується на державному рівні між MO3 та ДСНС, на регіональному, місцевому та об'єктовому рівнях - між структурними підрозділами з питань охорони здоров'я обласних, Київської та Севастопольської міських державних адміністрацій та територіальними органами ДСНС, територіальними органами центральних органів виконавчої влади, місцевими органами виконавчої влади, їх силами, а також суб'єктами господарювання у сфері охорони здоров'я, в тому числі закладами громадського здоров'я.

Взаємодія під час здійснення заходів щодо запобігання виникненню надзвичайних ситуацій та під час ліквідації їх наслідків організовується через спеціально призначені оперативні групи або представників відповідних центральних та місцевих органів виконавчої влади, органів місцевого самоврядування, які залучаються до здійснення таких заходів. 
Основні складові сил реагування та надання ЕМД постраждалим при НС в США в повсякденних умовах представлені розвиненою національною системою США «Emergency Medical Services (EMS)» - «невідкладної медичної допомоги», чи, як трактують цей термін сьогодні «екстреною медичною допомогою»).

Система ЕМД $€$ невід'ємною частиною системи реагування на стихійні лиха, техногенні катастрофи, терористичні акції. Вона $є$ найбільш оперативною i мобільною службою охорони здоров'я в кмовах повсякденної діяльності і першою прийде на допомогу постраждалим мешканцям при HC. Тому при плануванні медичного захисту населення, ліквідації медико-санітарних наслідків НС на даній території використовуються всі можливості системи ЕМД.

Основні фінансові витрати федеральної системи NDMS витрачаються на створення резервного ліжкового фонду пересувних та розгорнутих на базі великих лікарень усіх форм власності для забезпечення надання спеціалізованої медичної допомоги. Ліжкофонд лікарень виділяється в державних i навіть приватних лікарнях безкоштовно, але здійснюється оплата запасів медичного обладнання, технічних засобів, медикаментів та транспорту формувань і клінічної бази (запаси створюються із розрахунку роботи в зоні НС протягом 14 діб із запланованим навантаженням).

Англо-американська модель надання ЕМД базується навколо філософії «підбери та відвези» [12]. Такий підхід означає мінімальні заходи для стабілізації стану пацієнта та швидке транспортування до найближчого медичного закладу. Таким чином, основною метою допомоги $\epsilon$ якнайшвидша доставка пацієнта до лікарні. Зазвичай така система вимагає більш тісної співпраці з іншими рятувальними та правоохоронними службами, ніж 3 медичними закладами та самою системою охорони здоров'я [13].
Згідно з Законом України «Про екстрену медичну допомогу» основний тягар лягає на екстрену медичну допомогу.

Ст. 5. Основні засади організації та функціонування системи екстреної медичної допомоги

1. Система екстреної медичної допомоги в Автономній Республіці Крим, областях, містах Києві та Севастополі складається 3 центрів екстреної медичної допомоги та медицини катастроф, станцій екстреної (швидкої) медичної допомоги, бригад екстреної (швидкої) медичної допомоги, відділень екстреної (невідкладної) медичної допомоги.

2. Основними завданнями системи екстреної медичної допомоги є організація та забезпечення:

- надання доступної, безоплатної, своєчасної та якісної екстреної медичної допомоги відповідно до цього Закону, у тому числі під час виникнення надзвичайних ситуацій та ліквідації їх наслідків;

- медико-санітарного супроводу масових заходів та заходів за участю осіб, стосовно яких здійснюється державна охорона;

взаємодії 3 аварійно-рятувальними підрозділами міністерств, інших центральних та місцевих органів виконавчої влади під час виникнення надзвичайних ситуацій та ліквідації їх наслідків [2].

Згідно з наказом МОЗ від 18.02.2015 р. № 75 «Про додаткові заходи щодо забезпечення функціонування закладів охорони здоров'я в умовах особливого періоду та подолання наслідків НС державного рівня соціального та воєнного характеру» передбачено:

в пп.1 п. 1. Забезпечити роботу 303 у режимі підвищеної готовності, створивши резерв профільних ліжок (не менше 30\%) для надання невідкладної медичної допомоги постраждалим;

в пп.2. п. 3 забезпечити спеціалізовані медичні бригади II черги медицини катастроф необхідним запасом медикаментів та виробів медичного призначення 3 розрахунку на 3 доби роботи [18].

Практика надання ЕМД в Україні помітно відрізняється від практики у Північній Америці [30]. Також система ЕМД України не зовсім відповідає німецькій моделі. Яка ж модель ЕМД прийнятна для України?

Це питання стало актуальним у світлі реформування системи та прийняття Закону України «Про екстрену медичну допомогу» [2]. Він увібрав у себе зразки кращих напрацювань світових держав, де вже впроваджена й успішно працює така система. Головним завданням нововведень $є$ створення єдиної потужної служби, яка забезпечуватиме максимально оперативний та ефективний порятунок життів та збереження здоров’я українців. 
Служба ЕМД, як правило, обслуговує одну адміністративну територію або конкретний регіон 3 однаковими природними умовами, який лежить в межах декількох адміністративних територій. Планування діяльності в межах зони обслуговування потребує уміння об'єднувати зусилля сусідніх територій, регіонів. Законодавство зобов'язує владні структури та взаємозацікавлені структури сусідніх регіонів мати постійні добросусідські стосунки і передбачати в своїх планах різного типу взаємодопомогу.

\section{Система надання ЕМД в Україні}

В Україні діє служба ШМД - правонаступниця аналогічної служби, розбудованої в СРСР у минулому столітті за моделлю академіка Семашка, яку в багатьох чинних правових та нормативних актах $\mathrm{i}$ виступах керівників відомств Міністерства охорони здоров'я (МO3) України називають співзвучно «Служба екстреної медичної допомоги України» i намагаються ідентифікувати у правовому просторі чинного в Україні Закону «Про екстрену медичну допомогу» як українську систему екстреної медичної допомоги, подібно такій у США, що по суті не відповідає істині.

Доцільно відзначити, що в структурі служб ЕМД України та в органах управління нею передбачені юридичні підрозділи: в територіальному центрі ЕМД та медицини катастроф - юридична служба, в інших підрозділах - штатні юристи. Кожний документ (наказ, угода, акт тощо) перед підписом керівника має перевірятись і візуватись юристом. На жаль, юридичний нагляд у системі ЕМД за дотриманням вимог нормативноправового поля держави в повному обсязі не забезпечується внаслідок дефіциту зазначених фахівців.

Як показав досвід контролю (звіти територіальних центрів ЕМД та медицини катастроф за 2016 р.), зв'язок бригад ШМД з місця пригоди 3 приймальним відділенням лікарні, куди буде доставлений пацієнт в Україні, у $80 \%$ не спостерігається (Державний заклад «Центр медичної статистики Міністерства охорони здоров'я України», 2017). Тим більше, що, згідно 3 нормативними документами України, бригада має зв'язатись i консультуватися не $з$ лікарем приймального відділення, а 3 лікарем-консультантом диспетчерської служби адміністративної території (а не лікарні!).

Згідно 3 нормативом обслуговування, на одну бригаду ЕМД в середньому покладається територія 3 населенням 40 тис. жителів. Норматив обслуговування однією бригадою ЕМД одного виклику тривалістю до 1 год, тобто навантаження на одну бригаду ЕМД повинно складати 25 виїздів протягом доби. Час доїзду бригади ЕМД регламентований постановою КМУ від 21.11.2012 p. № 1119 «Про норматив прибуття бригад екстреної (швидкої) медичної допомоги на місце події» [17].

1) звернення стосовно надання екстреної медичної допомоги за єдиним телефонним номером екстреної медичної допомоги 103 або за єдиним телефонним номером системи екстреної допомоги населенню 112 залежно від стану пацієнта поділяються на екстрені та неекстрені згідно з додатком;
2) нормативи прибуття бригад екстреної (швидкої) медичної допомоги на місце події за зверненнями, що належать до категорії екстрених, становлять у містах 10 хвилин, у населених пунктах поза межами міста 20 хвилин 3 моменту надходження звернення до диспетчера оперативно-диспетчерської служби центру екстреної медичної допомоги та медицини катастроф.

Зазначені нормативи 3 урахуванням метеорологічних умов, сезонних особливостей, епідеміологічної ситуації та стану доріг можуть бути перевищені, але не більше ніж на 10 хвилин.

Надання ЕМД бригадами ЕМД регламентолвано наказом МО3 України від 05.06.2019 р. № 1269 «Про затвердження та впровадження медико-технологічних документів зі стандартизації екстреної медичної допомоги» [19].

До введення в дію Закону України «Про екстрену медичну допомогу діяли розпорядження КМУ від 25.11.2009 р. № 1426-р «Про схвалення концепції Закону України «Про зальнодержавну систему надання ЕМД»[20] та наказ МО3 України від 01.06.2009 р. № 370 «Про єдину систему надання екстреної медичної допомоги»[21], які не були виконані в повному обсязі.

Підготовка, перепідготовка та підвищення кваліфікації медичного персоналу регламентовано постановою КМУ від 21.11.2012 р. № 1115 «Про затвердження Порядку підготовки та підвищення кваліфікації осіб, які зобов'язані надавати домедичну допомогу» [23].

В Україні водії санітарного автотранспорту, як і медичний склад бригади, не мають соціального захисту, аналогічного тому, що має персонал бригад ЕМД США: страхування на випадок ризиків роботи (не завжди при виїздах у соціально небезпечні регіони їх супроводжує поліція чи сили безпеки) постанова КМУ від 21.11.2012 р. № 1114 «Про затвердження Типового положення про бригаду екстреної (швидкої) медичної допомоги» [22].

Служба протягом звітного періоду не розвивалася, концепція іiі структури та діяльності здавалася керівництву MO3 України логічною. Уніфіковане державне управління задовольняло недостатньо кваліфікований апарат MO3 України. Спочатку управління було повністю централізоване, а потім формально частково передано в комунальне управління адміністративних територій. Ніякого реального впливу на реформу служби ШМД громадських структур і вчених колективів України за означений період не зареєстровано. Водночас продовжувались заходи центрального апарату MO3 України щодо централізованих закупівель автомобільного санітарного транспорту, медикаментів і медичної апаратури. Відсутність системи страхової медицини, функціонального управління фахівцями, постійні проблеми 3 фінансуванням наклали свій відбиток на реалізацію заходів реформування. Працівники служби не мають реального соціального захисту i достатнього фінансового забезпечення. Вартий уваги штатний склад служби, який за віковим станом, станом здоров'я поступається за якістю більшості цих показників інших держав. 
Зміни стану з 1990 р., на жаль, мали суто технічний характер, що відображалось виведенням станцій ШМД зі складу базових лікарень, періодичними змінами кількості та якості бригад тощо.

Цікаво, що аналіз діяльності паралельно діючих в державі приватних систем і бригад ШМД у відкритих статистичних матеріалах і наукових працях не проводився.

Нормативно-правові документи потребують узгодження та серйозної розробки. Необхідно розробити i включити в дію систему громадського контролю фінансування діяльності ШМД, зупинити активну роботу щодо реалізації неіснуючої концепції майбутньої служби ШМД. Створити колективний тимчасовий орган за участю іноземних фахівців і вітчизняних вчених і розробити концепцію, затверджену владними структурами держави та Всесвітньої організації охорони здоров'я. Водночас потрібно завершити в державі адміністративнотериторіальну реформу та реформу реорганізації системи охорони здоров’я.

\section{Висновки}

Основними причинами принципових відмінностей концепцій надання ЕМД потерпілим при $\mathrm{HC} є$ те, що в США протягом останніх десятиліть принципово на всіх рівнях державного управління реалізовувалась єдина концепція, в основу якої закладено матеріальні, наукові та моральні фактори заохочення населення.

США мають унікальну за своєю ефективністю та якістю систему ЕМД, яка в реальних умовах сьогодення може бути прикладом для впровадження в Україні.

\section{Пропозиції щодо розвитку функціональної підсистеми медичного захисту населення в сдиній державній системі цивільного захисту}

1. Матеріальне, кадрове та фінансове підсилення підсистеми «охорона здоров'я» урядової інформаційноаналітичної системи з питань НС.

2. Створення сучасних навчально-тренувальних центрів для підготовки персоналу для роботи з надання медичної допомоги в умовах НС природного, техногенного, соціального та воєнного характеру (з наявністю класів симуляційного навчання).

3. Створення мобільних загонів медицини катастроф територіального рівня, як організаційної форми роботи бригад постійної готовності II черги з відповідним медичним, технічним та транспортним оснащенням.

4. Підсилення кадрового, матеріального та фінансового ресурсу мобільного загону медицини катастроф державного рівня (ДЗ «Український НПЦ екстреної медичної допомоги та медицини катастроф МО3 України»).

5. Створення оперативного резерву лікарських засобів та медичних виробів МОЗ України для забезпечення оперативного реагування міністерства на виникнення НС.

6. На виконання наказу МОЗ України 2015 р. № 75 «Про додаткові заходи щодо забезпечення функціонування закладів охорони здоров'я в умовах особливого періоду та подолання наслідків НC державного рівня соціального та воєнного характеру»створення реального резерву ліжок та медичних виробів у закладах охорони здоров'я на випадок виникнення НС.

\section{Література}

1. Конституція України. Прийнята на 5 сесії Верховної Ради України 28.06.1996 р.

2. Закон України «Про екстрену медичну допомогу», від 5 липня 2012 р № 5081-V.

3. Закон України «Кодекс цивільного захисту України», від 02.10.2012 p. № 5403-V1.

4. Близнюк М.Д., Печиборщ В.П., Михайловський М.М., Шуригін О.Ю. Особливості діяльності Національної системи невідкладної медичної допомоги США «Emergency Medical Services». Український медичний часопис. № 5/121, IX/X. 2017. С 80-83.

5. Смайли Д.Р. (2002) Федеральный стандарт DOT (ККК 1822C). Краткий обзор систем неотложной медицинской помощи. Информационный сборник АМОЗ. Нью-Йорк, 1: 1-26.

6. «Про затвердження Положення про функціональну підсистему медичного захисту населення», яке затверджено наказом МОЗ України від 25.03. 2019 р. № 667.

7. «Про затвердження Положення про медичну спеціалізовану службу цивільного захисту», яке затверджено наказом МОЗ України від 12.06.2019 р. № 1349 та зареєстровано в Мінюсті України 09.07.2019 р. за № 758/33759.

8. Постанова КМУ від 11.07.2001 р.№ 827 «Про затвердження Положення про Державну службу медицини катастроф».

9. Розпорядження КМУ від 22.05. 2019 р. № 383-р «Про схвалення Концепції розвитку системи екстреної медичної допомоги».

10. Закон України «Про правовий режим надзвичайного стану».

11. Закон України «Про правовий режим воєнного стану»,

12. Закон України «Про мобілізаційну підготовку та мобілізацію»,

13. Закон України «Про систему екстреної допомоги населенню за єдиним телефонним номером 112» від 13.03.2012 p. № 4499.

14. Постанова Кабінету Міністрів України від 21.11.2012 р. № 1121 «Про затвердження Порядку взаємодії закладів охорони здоров'я, що входять до системи екстреної медичної допомоги», з аварійно-рятувальними службами та підрозділами центральних та інших органів виконавчої влади, органі влади АР Крим, органів місцевого самоврядування під час виникнення надзвичайних ситуацій та ліквідації їх наслідків». 
15. Спільний наказ МВС та МОЗ України від 03.04.2018 р. № 275/600 та зареєстровано в Мінюсті 19.04.2018 р. за № 479/3931 «Про затвердження Інструкції щодо організації взаємодії між Державною службою України 3 надзвичайних ситуацій і Міністерством охорони здоров'я України у разі виникнення надзвичайних ситуацій».

16. Спільний наказ МВС та МОЗ України від 16.08.2018 р. № 677/1503 та зареєстровано в Мінюсті 30.10 .2018 за № 12321/32681 «Про затвердження Порядку спільних дій сил цивільного захисту та закладів охорони здоров’я під час здійснення аеромедичної евакуації повітряними суднами Державної служби України з надзвичайних ситуацій».

17. Постанова КМУ від 21.11.2012 р. № 1119 «Про норматив прибуття бригад екстреної (швидкої) медичної допомоги на місце події».

18. Наказ МОЗ від 18.02.2015 р. № 75 «Про додаткові заходи щодо забезпечення функціонування закладів охорони здоров’я в умовах особливого періоду та подолання наслідків НС державного рівня соціального та воєнного характеру».

19. Наказ МОЗ України від 05.06.2019 р. № 1269 «Про затвердження та впровадження медико-технологічних документів зі стандартизації екстреної медичної допомоги».

20. Розпорядження КМУ від 25.11.2009 р. № 1426-р «Про схвалення концепції Закону України «Про зальнодержавну систему надання ЕМД».

21. Наказ МОЗ України від 01.06.2009 р. № 370 «Про єдину систему надання екстреної медичної допомоги».

22. Постанова Кабінету Міністрів України від 21.11.2012 р. № 1114 «Про затвердження Типового положення про бригаду екстреної (швидкої) медичної допомоги».

23. Постанова Кабінету Міністрів України від 21.11.2012 р. № 1115 «Про затвердження Порядку підготовки та підвищення кваліфікації осіб, які зобов'язані надавати домедичну допомогу».

24. Система невідкладної медичної допомоги США. Особливості іiі організації та підготовки фахівців (довідковий посібник) / Під ред. Г.Г. Рощіна. МОЗ України, УНПЦ ЕМД та МК, КМАПО ім. П.Л. Шупика. К., 2004. - 204 c.

25. Курс обучения по неотложной медицинской помощи для курсантов. Медицинский центр Бостонского Университета. АМСЗ. - 1998. - 172 с.

26. Г.Г. Рощін, М.М. Михайловський, М.В. Нацюк, Концепція організації та функціонування невідкладної медичної допомоги в США, - «Медицина неотложных состояний» 1(1) 2005.

\section{References}

1. Konstytutsiia Ukrainy. Pryiniata na 5 sesii Verkhovnoi Rady Ukrainy 28.06.1996 r.

2. Zakon Ukrainy «Pro ekstrenu medychnu dopomohu», vid 5 lypnia 2012 r № 5081-V.

3. Zakon Ukrainy «Kodeks tsyvilnoho zakhystu Ukrainy», vid 02.10.2012 r. № 5403-V1.

4. Blyzniuk M.D., Pechyborshch V.P., Mykhailovskyi M.M., Shuryhin O.Iu..Osoblyvosti diialnosti Natsionalnoi systemy nevidkladnoi medychnoi dopomohy SShA «Emergency Medical Services». Ukrainskyi medychnyi chasopys № 5/121, IKh/Kh. 2017. S 80-83.

5. Smajli D.R. (2002) Federal'nyj standart DOT (KKK 1822S). Kratkij obzor sistem neotlozhnoj medicinskoj pomoshchi. Informacionnyj sbornik AMOZ. N'yu-Jork, 1: 1-26.

6. «Pro zatverdzhennia Polozhennia pro funktsionalnu pidsystemu medychnoho zakhystu naselennia», yake zatverdzheno nakazom MOZ Ukrainy vid 25.03. 2019 r. № 667.

7. «Pro zatverdzhennia Polozhennia pro medychnu spetsializovanu sluzhbu tsyvilnoho zakhystu», yake zatverdzheno nakazom MOZ Ukrainy vid 12.06.2019 r. № 1349 ta zareiestrovano v Miniusti Ukrainy 09.07.2019 r. za № 758/33759.

8. Postanova KMU vid 11.07.2001 r.№ 827 «Pro zatverdzhennia Polozhennia pro Derzhavnu sluzhbu medytsyny katastrof».

9. Rozporiadzhennia KMU vid 22.05. 2019 r. № 383-r «Pro skhvalennia Kontseptsii rozvytku systemy ekstrenoi medychnoi dopomohy».

10. Zakon Ukrainy «Pro pravovyi rezhym nadzvychainoho stanu».

11. Zakon Ukrainy «Pro pravovyi rezhym voiennoho stanu»,

12. Zakon Ukrainy «Pro mobilizatsiinu pidhotovku ta mobilizatsiiu»,

13. Zakon Ukrainy «Pro systemu ekstrenoi dopomohy naselenniu za yedynym telefonnym nomerom 112» vid 13.03.2012 r. № 4499.

14. Postanova Kabinetu Ministriv Ukrainy vid 21.11.2012 r. № 1121 «Pro zatverdzhennia Poriadku vzaiemodii zakladiv okhorony zdorovia, shcho vkhodiat do systemy ekstrenoi medychnoi dopomohy», z avariino-riatuvalnymy sluzhbamy ta pidrozdilamy tsentralnykh ta inshykh orhaniv vykonavchoi vlady, orhani vlady AR Krym, orhaniv mistsevoho samovriaduvannia pid chas vynyknennia nadzvychainykh sytuatsii ta likvidatsii yikh naslidkiv».

15. Spilnyi nakaz MVS ta MOZ Ukrainy vid 03.04.2018 r. № 275/600 ta zareiestrovano v Miniusti 19.04 .2018 r. za № 479/3931 «Pro zatverdzhennia Instruktsii shchodo orhanizatsii vzaiemodii mizh Derzhavnoiu sluzhboiu Ukrainy z nadzvychainykh sytuatsii i Ministerstvom okhorony zdorovia Ukrainy u razi vynyknennia nadzvychainykh sytuatsii». 
16. Spilnyi nakaz MVS ta MOZ Ukrainy vid 16.08.2018 r. № 677/1503 ta zareiestrovano v Miniusti 30.10.2018 r. za № 12321/32681 «Pro zatverdzhennia Poriadku spilnykh dii syl tsyvilnoho zakhystu ta zakladiv okhorony zdorovia pid chas zdiisnennia aeromedychnoi evakuatsii povitrianymy sudnamy Derzhavnoi sluzhby Ukrainy z nadzvychainykh sytuatsii».

17. Postanova KMU vid 21.11.2012 r. № 1119 «Pro normatyv prybuttia bryhad ekstrenoi (shvydkoi) medychnoi dopomohy na mistse podii»».

18. Nakaz MOZ vid 18.02.2015 r. № 75 «Pro dodatkovi zakhody shchodo zabezpechennia funktsionuvannia zakladiv okhorony zdorovia $\mathrm{v}$ umovakh osoblyvoho periodu ta podolannia naslidkiv NS derzhavnoho rivnia sotsialnoho ta voiennoho kharakteru».

19. Nakaz MOZ Ukrainy vid 05.06.2019 r. № 1269 «Pro zatverdzhennia ta vprovadzhennia medyko-tekhnolohichnykh dokumentiv zi standartyzatsii ekstrenoi medychnoi dopomohy».

20. Rozporiadzhennia KMU vid 25.11.2009 r. № 1426-r «Pro skhvalennia kontseptsii Zakonu Ukrainy «Pro zalnoderzhavnu systemu nadannia EMD».

21. Nakaz MOZ Ukrainy vid 01.06.2009 r. № 370 «Pro yedynu systemu nadannia ekstrenoi medychnoi dopomohy».

22. Postanova Kabinetu Ministriv Ukrainy vid 21.11.2012 r. № 1114 «Pro zatverdzhennia Typovoho polozhennia pro bryhadu ekstrenoi (shvydkoi) medychnoi dopomohy».

23. Postanova Kabinetu Ministriv Ukrainy vid 21.11.2012 r. № 1115 «Pro zatverdzhennia Poriadku pidhotovky ta pidvyshchennia kvalifikatsii osib, yaki zoboviazani nadavaty domedychnu dopomohu».

24. Systema nevidkladnoi medychnoi dopomohy SShA. Osoblyvosti yii orhanizatsii ta pidhotovky fakhivtsiv (dovidkovyi posibnyk) / Pid red. H.H. Roshchina. MOZ Ukrainy, UNPTs EMD ta MK, KMAPO im. P.L. Shupyka. K., 2004. - 204 s.

25. Kurs obuchenyia po neotlozhnoi medytsynskoi pomoshchy dlia kursantov. Medytsynskyi tsentr Bostonskoho Unyversyteta. AMSZ. - 1998. - 172 s.

26. H.H. Roshchin, M.M. Mykhailovskyi, M.V. Natsiuk, Kontseptsiia orhanizatsii ta funktsionuvannia nevidkladnoi medychnoi dopomohy v SShA, - «Medicina neotlozhnyh sostoyanij» 1(1) 2005.

Дата надходження рукопису до редакції: 21.08.2020 p.

Мета. Порівняти стан та організацію функціональної підсистеми медичного захисту населення в єдиній державній системі цивільного захисту США та України для оптимізації ії діяльності в підготовчий період та ефективного реагування в процесі подолання наслідків надзвичайних ситуацій (НС) та якісного і своєчасного надання екстреної медичної допомоги (ЕМД) потерпілим в НС мирного часу, особливого періоду та під час терористичних акцій.

Матеріали та методи. У дослідженні використані нормативно-правові документи держави, наукові публікації, матеріали науково-практичних конференцій та проведено порівняльний аналіз організації функціональної підсистеми медичного захисту населення США та України.

Результати. На основі проаналізованого досвіду діяльності функціональної підсистеми медичного захисту населення в єдиній державній системі цивільного захисту США та України визначені проблеми, пріоритетні завдання та шляхи їх вирішення. Проведений детальний аналіз недоліків нормативно-правового та матеріально-технічного забезпечення діяльності функціональної підсистеми медичного захисту населення в єдиній державній системі цивільного захисту США та України.

Висновки. Встановлено ряд проблем діяльності функціональної підсистеми медичного захисту населення в єдиній державній системі цивільного захисту. Порівняно результати діяльності служби функціональної підсистеми медичного захисту населення в єдиній державній системі цивільного захисту України та ряду країн світу. Надано пропозиції щодо діяльності та вирішення проблем функціональної підсистеми медичного захисту населення в єдиній державній системі цивільного захисту.

Ключові слова функціональна підсистема медичного захисту населення США та України, порівняльний аналіз.

Цель. Сравнить состояние и организацию функциональной подсистемы медицинской защиты населения в единой государственной системе гражданской защиты США и Украины для оптимизации ее деятельности в подготовительный период и эффективного реагирования в процессе преодоления последствий чрезвычайных ситуаций (ЧС) и качественного и своевременного оказания экстренной медицинской помощи (ЭМП) пострадавшим в ЧС мирного времени, особого периода и вовремя террористических акций.

Материалы и методы. В исследовании использованы нормативно-правовые документы государства, научные публикации, материалы научно-практических конференций и проведен сравнительный анализ организации функциональной подсистемы медицинской защиты населения США и Украины.

Результаты. На основе проанализированного опыта деятельности функциональной подсистемы медицинской защиты населения в единой государственной системе гражданской защиты США и Украины определены проблемы, приоритетные задачи и пути их решения. Проведен детальный анализ недостатков нормативно-правового и 
материально-технического обеспечения деятельности функциональной подсистемы медицинской защиты населения в единой государственной системе гражданской защиты США и Украины.

Выводы. Установлен ряд проблем деятельности функциональной подсистемы медицинской защиты населения в единой государственной системе защиты населения. Проведен сравнительный анализ результатов деятельности службы функциональной подсистемы медицинской защиты населения в единой государственной системе гражданской защиты Украины и ряда стран мира. Даны предложения по улучшению деятельности и решения проблем функциональной подсистемы медицинской защиты населения в единой государственной системе защиты населения.

Ключевые слова: функциональная подсистема медицинской защиты населения США и Украины, сравнительный анализ.

Purpose. Compare the state and organization of the functional subsystem of medical protection of the population in the unified state civil protection system of the United States and Ukraine to optimize its activities during the preparatory period and effectively respond in the process of overcoming the consequences of emergencies (ES) and high-quality and timely provision of emergency medical care (EMF) to victims in Emergency situations of peacetime, special period and during terrorist acts.

Materials and methods. The study used state regulatory documents, scientific publications, materials of scientific and practical conferences and carried out a comparative analysis of the organization of the functional subsystem of medical protection of the population of the United States and Ukraine.

Results. Based on the analyzed experience of the functioning of the functional subsystem of medical protection of the population in the unified state civil protection system of the United States and Ukraine, problems, priority tasks and ways of solving them are identified. A detailed analysis of the shortcomings of the regulatory and material and technical support of the functional subsystem of medical protection of the population in the unified state civil protection system of the United States and Ukraine is carried out.

Conclusions. A number of problems of the activity of the functional subsystem of medical protection of the population in the unified state system of protection of the population have been established. A comparative analysis of the results of the activity of the service of the functional subsystem of medical protection of the population in the unified state system of civil protection of Ukraine and several countries of the world is carried out. Suggestions for improving the activity and solving problems of the functional subsystem of medical protection of the population in the unified state system of protection of the population are given.

Key words: functional subsystem of medical protection of the population of the USA and Ukraine, comparative analysis.

Конфлікт інтересів: відсутній.

Conflicts of interest: authors have no conflicts of interest to declare.

\section{Відомості про авторів}

Якимець Володимир Миколайович - Заслужений лікар України, доктор медичних наук, професор, заступник директора 3 науково-організаційної та методичної роботи ДНУ «Центр інноваційних медичних технологій НАН України»; 04053, м. Київ, Вознесенський узвіз, 22.

Печиборщ В'ячеслав Петрович - Заслужений працівник охорони здоров’я України, доктор медичних наук, доцент, завідувач відділу науково-організаційної роботи та інформації ДНУ «Центр інноваційних медичних технологій НАН України»; 04053, м. Київ, Вознесенський узвіз, 22.

Волянський Петро Борисович - Заслужений лікар України, доктор наук з державного управління, професор, заступник начальника Інституту державного управління та наукових досліджень з цивільного захисту, В.о. начальника інституту; м. Київ, вул. Вишгородська, 21.

Кушнір Віталій Андрійович - к.мед.н., старший науковий співробітник, завідувач кафедри домедичної підготовки Інституту державного управління та наукових досліджень з цивільного захисту; м. Київ, вул. Вишгородська, 21.

Вороненко Володимир Васильович - заступник директора Державної установи «Науково-практичний медичний центр дитячої кардіології та кардіохірургії Міністерства охорони здоров’я»; 01135, м. Київ, вул. В’ячеслава Чорновола 28/1.

Слабкий Геннадій Олексійович - д.мед.н. професор, завідувач кафедри громадського здоров’я факультету післядипломної освіти та доуніверситетської підготовки ДВНЗ «Ужгородський національний університет»; 88000, м. Ужгород, пл. Народна 3, Україна. 